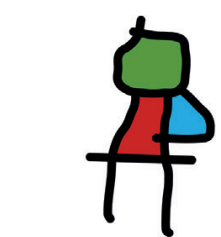

SEICAIP

\section{Allergologia et immunopathologia}

Sociedad Española de Inmunología Clínica, Alergología y Asma Pediátrica

www.all-imm.com

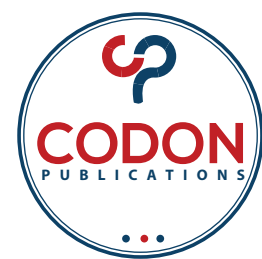

\title{
Hygiene hypothesis: association between hygiene and asthma among preschool children in Lebanon
}

\author{
Souheil Hallit ${ }^{a, b *}$, Hala Sacre ${ }^{b}$, Nelly Kheir ${ }^{c}$, Eva Hobeika ${ }^{d}$, Rabih Hallit ${ }^{a, e, f}$, Mirna Wakeds, \\ Pascale Salameh ${ }^{\mathrm{b}, \mathrm{h}, \mathrm{i}}$
}

${ }^{a}$ Faculty of Medicine and Medical Sciences, Holy Spirit University of Kaslik (USEK), Jounieh, Lebanon

bInstitut National de Santé Publique (INSPECT-LB), Epidémiologie Clinique et Toxicologie - Liban, Beirut, Lebanon

'Research Department, Psychiatric Hospital of the Cross, Jal Eddib, Lebanon

${ }^{d}$ Faculty of Arts and Sciences, Holy Spirit University of Kaslik (USEK), Jounieh, Lebanon

'Department of Infectious Disease, Notre Dame des Secours University Hospital, Byblos, Lebanon

${ }^{f}$ Department of Infectious Disease, Bellevue Medical Center, Mansourieh, Lebanon

s Department of Pulmunology, Saint Georges Hospital, Achrafieh, Lebanon

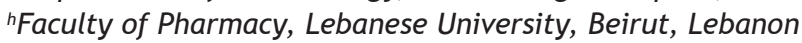

${ }^{i}$ Faculty of Medicine, University of Nicosia, Nicosia, Cyprus

Received 22 May 2020; Accepted 13 July 2020

Available online 2 January 2021

\section{KEYWORDS \\ hygiene; \\ hypothesis; \\ asthma; \\ preschool; \\ children}

\begin{abstract}
Objectives: To validate a scale to assess the hygiene hypothesis and the association between hygiene and asthma among Lebanese preschool children aged 3-5 years.

Methods: This cross-sectional study, conducted between November 2018 and March 2019, enrolled 515 preschool children. Asthma and potential risk factors, including hygiene, were assessed using a standardized questionnaire. A specific hygiene hypothesis scale has been generated and validated for this purpose.

Results: The hygiene hypothesis scale items converged over a solution of nine factors that had an Eigenvalue over 1, explaining a total of $65.86 \%$ of the variance. An acceptable Cronbach's alpha value was recorded for the hygiene hypothesis scale (0.696). Variables correlated with higher odds of asthma were male gender ( $\mathrm{ORa}=0.41$ for females), living near a prairie sprayed with pesticides $(\mathrm{ORa}=3.09)$, having a heating system in the bedroom compared to the sitting room $(\mathrm{ORa}=9.97)$, attending kindergarten $(\mathrm{ORa}=2.80)$, having a mother who smokes waterpipe compared to not smoking $(\mathrm{ORa}=3.34)$, having a mother with a history of asthma $(\mathrm{ORa}=$ $5.50)$, and having respiratory infections $(\mathrm{ORa}=14.72)$. However, the hygiene hypothesis score was not associated with higher odds of asthma $(p=0.881)$.

Conclusions: The current results suggested that neither home cleaning nor personal cleanliness was correlated with asthma in preschool children. Larger prospective studies that measure the intensity and duration of exposure to each toxicant are suggested to better assess the hygiene hypothesis items and their association with asthma.

(c) 2021 Codon Publications. Published by Codon Publications.
\end{abstract}




\section{Introduction}

Asthma is one of the most common respiratory illnesses worldwide. ${ }^{1}$ Despite progress in healthcare and pharmacotherapy, its prevalence is still on the rise and varies between 2 and 30\% according to an international multicenter study. ${ }^{2}$ The prevalence of asthma may now be increasing in formerly low-risk, low- and middle-income countries, while it has reached a plateau in many high-risk, high-income countries. ${ }^{2}$ High rates of asthma have been reported in some low-income cities, ${ }^{2}$ where overcrowding, poor hygiene, and a high burden of infectious diseases prevail.

Nevertheless, the "hygiene hypothesis" introduced by Strachan in $1989^{3}$ provides a widely accepted explanation for the increase in the prevalence of asthma and allergies in industrialized countries: reduced exposure to certain micro-organisms at an early age is purported to increase the risk of allergic diseases at a later stage in life. ${ }^{4}$ The U.S. Food and Drug Administration defines the hygiene hypothesis to the lay public as "the extremely clean household environments, often found in the developed world, that fail to provide the necessary exposure to germs required to 'educate' the immune system so it can learn to launch its defense responses to infectious organisms". ${ }^{5}$ It has been suggested for decades that living on a farm during childhood or being born to a mother exposed to a farm environment during pregnancy could have protective effects against asthma by modulating the immune system and deviating it to non-allergic pathways. ${ }^{6}$ This theory underwent several changes; at first, it was based on the fact that "allergic diseases were prevented by an infection in early childhood, transmitted by unhygienic contact with older siblings". ${ }^{3}$ More recently, with the increased use of detergents and disinfectants in homes, the focus shifted from the infection theory to that of "sterile" houses, thus introducing the "cleanliness hypothesis".

\section{Arguments in favor of the hygiene hypothesis}

The hygiene hypothesis takes into consideration the active role that the personal microbiome plays from conception and throughout life ${ }^{8}$ : maternal microbes colonize the human gut when babies are in utero, during birth, and during breastfeeding. ${ }^{8}$ The first few years of life is the limited time-frame during which the immune system correctly matures through exposure to microbes. Otherwise, disrupted host-microbe interactions may occur, paving the way for immunological reactions that further lead to the emergence of allergic diseases. ${ }^{9}$ During childhood, every contact with family members, playing in the dirt, and sharing toys lead to collecting microbiota. Based on these contacts, the immune system develops eventually. ${ }^{8,10}$ Moreover, the excessive use of antibiotics, particularly during pregnancy, may affect gut microbiota and increase the risk of allergic disorders in early childhood.11-13 In addition, changes in maternal microbiota by antibiotics/inadequate diet cause not only acute effects but are also transmitted to future generations. ${ }^{14}$ Later in life, the microbiome will be affected by urbanization, and changes in environment and lifestyle that are contributing factors to altered exposure to important microbes. ${ }^{11}$ Poor hygiene resulting from the exposure to some environmental factors is linked with higher interleukin-10,15 providing a biologically plausible association between continuous bacterial exposure and decreased tissue inflammation. The association between childhood infections, atopic diseases, and unfavorable childhood experiences reveals an immune-mediated system that integrates and even surpasses the hygiene hypothesis. ${ }^{16}$

\section{Arguments opposed to the hygiene hypothesis}

Several facts contradict the hygiene hypothesis, such as parasitic worms whose effect on asthma varies according to several factors, including species, intensity and duration of infection, and age at first infection. ${ }^{17}$ Moreover, recent epidemiological, molecular, and experimental evidence deviate the blame from personal hygiene measures. Hence, if the contact with microbial components and house dust through the airways causes asthma, then hygiene and cleanliness are unlikely to be responsible for this pathway. Consequently, hygiene measures do not have an impact on chronic inflammatory and allergic disorders. ${ }^{11}$

A review published in 2017 found that individualities could make certain factors either protective, or not, towards the development of asthma. Microbiome differences may be due to genetic and immunological differences between geographically distinct groups of people. Furthermore, microbial exposure has induced different effects on people depending on whether the germs were harmless or pathogenic. ${ }^{18}$ Communicable viral infections are another factor to be taken into consideration. Epidemiological studies in developing countries refute the link between the decreased risk of allergy and disease-causing germs. Indeed, research revealed that measles and respiratory diseases were non-protective against allergic diseases and that, in many cases, they have even increased the risk of allergies. ${ }^{19}$

\section{Assessing the hygiene hypothesis}

The major problem associated with studying hygiene behavior is how to measure it. Direct observation may be difficult, and, as with self-reporting, it may be affected by the participant's need to project socially desirable standards of hygiene. ${ }^{20}$ Regarding hand hygiene behavior, it is based on self-reports, observation, and proxy measures, such as illness rates and the use of soap. ${ }^{21}$ A first scale was developed and validated by Stevenson et al., ${ }^{22}$ taking into consideration all aspects of the hygiene hypothesis, including various forms of hygiene behavior. A few years later, drawing inspiration from Stevenson's scale and adding new items to it, Weber et al. ${ }^{7}$ created another scale to measure self-reported general, household, food-related, hand, and personal hygiene. Moreover, many studies on the composition of household dust have assessed household cleaning habits, such as sweeping the floor or changing bedding. ${ }^{23}$

\section{Hygiene measures and asthma}

Many epidemiological studies were conducted to test the hygiene hypothesis, and resulted in inconsistent findings, ${ }^{24}$ 
which may be explained by the use of different definitions and phenotypes of asthma (e.g., atopic vs. non-atopic) and various comparison groups. ${ }^{25}$ This inconsistency may also derive from different underlying mechanisms and associated environmental exposures, leading to difficulties in assessing hygiene components. Epidemiological research, directly evaluating the association between household or personal hygiene and the development of allergies, is scarce, and only studies conducted in developed and upper-middle-income economy countries (e.g., Germany, ${ }^{7}$ the Netherlands, ${ }^{26}$ and Belarus ${ }^{27}$ ) have demonstrated this relationship. In contrast, many studies have demonstrated the association between factors related to poor hygiene and higher odds of non-atopic asthma/wheezing. ${ }^{28,29}$ A systematic review of observational studies conducted in Latin America to evaluate the association between the hygiene hypothesis and asthma/wheezing revealed that most exposure studies did not show an association with wheezing or asthma. ${ }^{30}$

To the best of our knowledge, no studies have been conducted in Lebanon to assess the association between the hygiene hypothesis and asthma among children in Lebanon, a middle-income developing country with a high prevalence of asthma. ${ }^{31}$ Therefore, our objectives are to validate the scale created by Weber et al. to assess the hygiene hypothesis and to evaluate the association between hygiene and asthma among Lebanese preschool children aged 3-5 years.

\section{Methods}

\section{Study design}

This cross-sectional study was conducted, between November 2018 and March 2019, on a sample of preschool children aged 3-5 years drawn from three private schools in three different governorates in Lebanon. A total of 10 schools, from all districts in Lebanon (Beirut, Mount Lebanon, North, South, and Bekaa), were contacted; seven refused to participate. The three schools that accepted were located in three districts: Beirut, Mount Lebanon, and North Lebanon. The study questionnaire was sent to all parents since all preschool children in those schools were eligible to participate. Children whose parents refused to participate in this study were excluded.

\section{Sample size calculation}

In the absence of similar studies in Lebanon, the sample size was calculated using Epi info following the criteria hereafter: a population size of 6 million, a theoretical frequency of $50 \%$ of hygiene measures, and a $5 \%$ confidence limit. A sample of 384 children was calculated to provide adequate power for bivariate and multivariate analyses.

\section{Questionnaire and variables}

A pretested self-administered questionnaire used was adapted to the local Arabic language (the native language in Lebanon) from the standardized and validated American
Thoracic Society chronic respiratory disease questionnaire (International Study of Asthma and Allergies in Childhood ISAAC). It was translated into Arabic then back into English to ensure the accuracy of questions; next, it was pretested on a sample of 10 parents and required no modifications, thus, the recorded results were included in the study. The same questionnaire had already been used in Lebanon in studies with older children. ${ }^{32-35}$

The first part of the questionnaire assessed the socio-demographic characteristics of the children, including age, gender, region, number of rooms and number of persons living in the house, education level of both parents (assessed based on the number of years of schooling, i.e., illiterate, primary, complementary, secondary, university), family history of asthma, and other known risk factors of asthma (the heating system used at home, child history of recurrent otitis, humidity inside the house, child attending a nursery, etc.).

The second part included questions on the diagnosis and symptoms of asthma among children. The diagnosis of declared asthma was defined by an affirmative answer to the question: "Has your doctor ever told you that your child has asthma?", while chronic respiratory symptoms were defined by the presence of one of the following symptoms: recurrent wheezing (during the day, evening, night, the whole day, or at exercise), recurrent cough (during the day, evening, night, the whole day, or at exercise), a history of more than one episode of dyspnea with wheezing treated by a doctor. Questions about wheezing and night coughing without having a cold were also taken from the ISAAC questionnaire.

The third section included questions related to factors generally associated with asthma, namely parental asthma ${ }^{36}$; prenatal exposure to medications (antibiotics, paracetamol) ${ }^{36,37}$; alcohol use ${ }^{38}$ and smoking ${ }^{39,40}$ during pregnancy; preterm delivery ${ }^{41}$; passive smoking and environmental exposure to toxicants ${ }^{39,40}$; number of older siblings; medication or alcohol intake during breastfeeding; reflux; atopy; exposure to pesticides (occupational, regional, local, and domestic $)^{39,40}$; and the use of cleaning products at home. ${ }^{42}$ The exposure to pesticides was recorded using the following questions: "Have you ever used pesticides in your work?"; "Have you ever used pesticides out of your work (for house or garden treatment...)?’; “'Do you live in a region heavily treated by pesticides?"; "Do you live in the proximity of a heavily treated field by pesticides?" along with the duration of exposure during work (which can bring pesticides home through particles sticking to clothes) and the number of times the house or the garden gets sprayed by pesticides per week or year. Passive smoking was characterized by the number of smokers at home. The use of detergents was determined by questions about who uses these products at home, the type of detergents, and whether or not these products are mixed when cleaning the house. Additional information was also recorded regarding the heating system used at home, the presence of an air conditioner and humidifier, humidity or mold on the walls at home, a history of recurrent otitis of the child, tonsillectomy, cardiac problems, premature birth, and attending kindergarten.

This last section was dedicated to the hygiene hypothesis and consisted of 46 questions: 32 were taken from a 
previous study ${ }^{7}$ and 14 were added based on the Lebanese experience. Some examples include: "How many times do you clean the bathroom per week?"; "How many times do you clean the kitchen per week?"; "How many times do you wash the child's hands after playing outside? After using the toilet? Do you clean his hands with or without soap?" A total score was computed by summing the answers to all questions, with higher scores indicating more cleanliness at home.

\section{Statistical analysis}

Data analysis was performed on SPSS software, version 23. Descriptive statistics included the frequency (percentage) for categorical variables and mean (standard deviation) for continuous variables. The Chi-square test was used to evaluate the association between categorical variables and the presence/absence of asthma, whereas the Student t-test was used to evaluate the association between continuous variables and the dependent variable. To confirm the validity of the construct of the hygiene hypothesis questionnaire in the Lebanese population, a factor analysis was performed using the principal component analysis (PCA) technique, with a promax rotation since the extracted factors were found to be significantly correlated. The Kaiser-Meyer-Olkin (KMO) measure of sampling adequacy and Bartlett's test of sphericity were checked for adequacy. The retained number of factors corresponded to Eigenvalues higher than 1. Moreover, Cronbach's alpha was computed to assess the reliability of the total score and subscale factors. To minimize confounding, a backward logistic regression was performed, taking the presence/ absence of asthma as the dependent variable and taking all variables that showed a $p<0.1$ in the bivariate analysis as independent variables. In all cases, a p-value of less than 0.05 was considered significant.

\section{Results}

Out of 700 questionnaires distributed, 515 (73.57\%) were completed and collected back: 425 (82.5\%) were completed by the mother, $68(13.2 \%)$ by the father, and 22 (4.3\%) by both. The sociodemographic characteristics of the children are summarized in Table 1. The mean age of children was $4.44 \pm 0.83$ years, $46.0 \%$ were girls, the majority $(75.7 \%)$ lived in Mount Lebanon, and $8.2 \%$ [95\% Cl 5.8-10.5] were diagnosed with asthma.

\section{Factor analysis}

The PCA was run over the whole sample $(N=515)$ for the hygiene hypothesis scale. Out of all 46 items, 22 items were removed, either because of over-correlation to each other $(r>0.9)$, low loading on factors $(<0.3)$, or low communality $(<0.3)$. The remaining items converged over a solution of nine factors that had an Eigenvalue over 1, explaining a total of $65.86 \%$ of the variance $(\mathrm{KMO}=0.621$; Bartlett's test of sphericity, $\mathrm{p}<0.001$; $\mathrm{aCronbach}=0.696$ ) (Table 2).
Table 1 Sociodemographic characteristics of the children.

\begin{tabular}{lc}
\hline $\begin{array}{l}\text { Variable } \\
\text { Sex }\end{array}$ & $\begin{array}{c}\text { Frequency } \\
(\%)\end{array}$ \\
$\quad$ Male & $278(54.0 \%)$ \\
$\quad$ Female & $237(46.0 \%)$ \\
Mohafaza & \\
Beirut & $87(16.9 \%)$ \\
Mount Lebanon & $390(75.7 \%)$ \\
$\quad$ North/South/Bekaa & $38(7.4 \%)$ \\
Physician-diagnosed asthma & \\
No & $463(89.9 \%)$ \\
Yes & $42(8.2 \%)$ \\
\hline & Mean \pm SD \\
\hline Age (in years) & $4.44 \pm 0.83$ \\
Number of siblings older than the child & $0.85 \pm 0.98$ \\
Number of siblings younger than the child & $0.48 \pm 0.82$ \\
\hline
\end{tabular}

\section{Bivariate analysis}

The results of the bivariate analysis of factors associated with asthma are summarized in Table 3. A significantly higher proportion of boys compared to girls $(11.2 \%$ vs. 4.6\%). Additionally, those who had respiratory infections before the age of 2 (48.9\% vs. $6.2 \%)$; those living near a prairie sprayed with pesticides $(13.6 \%$ vs. $7.0 \%)$; playing outdoors $(11.1 \%$ vs. $4.9 \%)$; having respiratory problems preventing activities (20.6\% vs. $7.3 \%)$; born premature $(22.2 \%$ vs. $7.4 \%)$; attending kindergarten (10.6\% vs. $5.2 \%)$; having a father and brother with food allergy $(40.0 \%$ vs. $7.5 \%$ and $33.3 \%$ vs. $7.9 \%$, respectively); having a mother who smokes cigarette compared to waterpipe or both; having a father with an allergy to medications (50.0\% vs. $7.8 \%)$; having a sister with seasonal allergy $(28.6 \%$ vs. $7.6 \%)$; having a sister and a brother with allergic rhinitis $(100.0 \%$ vs. $7.6 \%$ and $40.0 \%$ vs. $7.8 \%$, respectively); having reflux (18.6\% vs. $7.2 \%)$; having had eczema before the age of 2 (17.6\% vs. $7.5 \%)$; and having a heater in the bedroom rather than in other rooms of the house had asthma.

Finally, no significant difference in terms of the hygiene hypothesis total score or any of its nine factors $(p>0.05$ for all variables) was found between children with or without asthma, and no significant difference was found between the hygiene score and the respiratory symptoms (wheezing, cough, and bronchial secretions) ( $p>0.05$ for all variables) (data not shown). Figure 1 shows the mean scores of hygiene hypothesis factors between asthmaticand non-asthmatic children.

\section{Multivariable analysis}

A backward logistic regression, taking the presence/ absence of asthma in a child as the dependent variable, 
Table 2 Promax rotated matrix of the hygiene hypothesis scale items.

\begin{tabular}{|c|c|c|c|c|c|c|c|c|c|}
\hline Factor & $\begin{array}{c}\text { Factor } \\
1\end{array}$ & $\begin{array}{c}\text { Factor } \\
2\end{array}$ & $\begin{array}{c}\text { Factor } \\
3\end{array}$ & $\begin{array}{c}\text { Factor } \\
4\end{array}$ & $\begin{array}{l}\text { Factor } \\
5\end{array}$ & $\begin{array}{c}\text { Factor } \\
6\end{array}$ & $\begin{array}{c}\text { Factor } \\
7\end{array}$ & $\begin{array}{l}\text { Factor } \\
8\end{array}$ & $\begin{array}{c}\text { Factor } \\
9\end{array}$ \\
\hline $\begin{array}{l}\text { Number of times of liquid detergent } \\
\text { use on the floor per week }\end{array}$ & 0.834 & & & & & & & & \\
\hline $\begin{array}{l}\text { Number of times of wiping the floor } \\
\text { per week }\end{array}$ & 0.737 & & & & & & & & \\
\hline $\begin{array}{l}\text { Number of times of dusting the house } \\
\text { per week }\end{array}$ & 0.674 & & & & & & & & \\
\hline $\begin{array}{l}\text { Number of times of liquid detergent } \\
\text { use on surfaces per week }\end{array}$ & 0.674 & & & & & & & & \\
\hline $\begin{array}{l}\text { Number of times of cleaning the } \\
\text { bathrooms per week }\end{array}$ & 0.650 & & & & & & & & \\
\hline $\begin{array}{l}\text { Number of times of whitening } \\
\text { products used per week }\end{array}$ & 0.627 & & & & & & & & \\
\hline $\begin{array}{l}\text { Number of times of cleaning the } \\
\text { kitchen per week }\end{array}$ & 0.564 & & & & & & & & \\
\hline $\begin{array}{l}\text { Number of times of washing the } \\
\text { child's hands with soap before } \\
\text { eating per day }\end{array}$ & & 0.905 & & & & & & & \\
\hline $\begin{array}{l}\text { Number of times of washing the } \\
\text { child's hands without soap before } \\
\text { eating per day }\end{array}$ & & 0.891 & & & & & & & \\
\hline $\begin{array}{l}\text { Number of times of washing the } \\
\text { child's hands with soap after } \\
\text { playing outside per day }\end{array}$ & & & 1 & & & & & & \\
\hline $\begin{array}{l}\text { Number of times of washing the } \\
\text { child's hands without soap after } \\
\text { playing outside per day }\end{array}$ & & & 0.991 & & & & & & \\
\hline $\begin{array}{l}\text { Number of times of washing the } \\
\text { child's hair with shampoo per } \\
\text { week }\end{array}$ & & & & 0.868 & & & & & \\
\hline $\begin{array}{l}\text { Number of times of showering the } \\
\text { child per week }\end{array}$ & & & & 0.844 & & & & & \\
\hline $\begin{array}{l}\text { Level of the parents' bedroom in the } \\
\text { house (which floor) }\end{array}$ & & & & & 0.872 & & & & \\
\hline $\begin{array}{l}\text { Level of the child's bedroom in the } \\
\text { house (which floor) }\end{array}$ & & & & & 0.856 & & & & \\
\hline Swimming in an indoor pool & & & & & & 0.707 & & & \\
\hline $\begin{array}{l}\text { Number of times of washing the } \\
\text { child's hands with soap after using } \\
\text { the toilet per day }\end{array}$ & & & & & & 0.649 & & & \\
\hline $\begin{array}{l}\text { Number of times of washing the } \\
\text { child's hands without soap after } \\
\text { using the toilet per day }\end{array}$ & & & & & & 0.645 & & & \\
\hline $\begin{array}{l}\text { Presence of compost containers } \\
\text { inside the house }\end{array}$ & & & & & & & 0.838 & & \\
\hline $\begin{array}{l}\text { Presence of compost containers } \\
\text { outside the house }\end{array}$ & & & & & & & 0.682 & & \\
\hline Number of pets at home & & & & & & & & 0.767 & \\
\hline Presence of a fish tank in the house & & & & & & & & 0.669 & \\
\hline Biting nails & & & & & & & & & 0.726 \\
\hline $\begin{array}{l}\text { Number of times of cutting nails per } \\
\text { month }\end{array}$ & & & & & & & & & 0.689 \\
\hline Cronbach's alpha & 0.805 & 0.817 & 0.977 & 0.691 & 0.617 & 0.667 & 0.290 & 0.222 & 0.228 \\
\hline Percentage of variances explained & 15.08 & 11.34 & 7.17 & 6.68 & 6.29 & 5.78 & 4.79 & 4.56 & 4.17 \\
\hline
\end{tabular}

Factor 1: cleaning the house; Factor 2: washing hands before eating; Factor 3: washing hands after playing outside; Factor 4: showering (body and hair); Factor 5: level of the bedrooms in the house (which floor); Factor 6: indoor swimming pool and washing hands after toilet use; Factor 7: the presence of compost in/out the house; Factor 8: the presence of animals in the house; Factor 9: nail-biting and cutting. 
Table 3 Bivariate analysis taking the presence/absence of asthma in a child as the dependent variable.

\begin{tabular}{|c|c|c|c|}
\hline & $\begin{array}{l}\text { Absence of asthma in child } \\
\qquad N=473(91.8 \%)\end{array}$ & $\begin{array}{l}\text { Presence of asthma in child } \\
\qquad N=42(8.2 \%)\end{array}$ & p-value \\
\hline Gender & & & 0.007 \\
\hline Male & 247 (88.8\%) & $31(11.2 \%)$ & \\
\hline Female & $226(95.4 \%)$ & $11(4.6 \%)$ & \\
\hline Living near a prairie sprayed with pesticides & & & 0.039 \\
\hline Yes & $76(86.4 \%)$ & $12(13.6 \%)$ & \\
\hline No & 397 (93.0\%) & $30(7.0 \%)$ & \\
\hline Respiratory infections before 2 years of age & & & $<0.001$ \\
\hline Yes & $23(51.1 \%)$ & $22(48.9 \%)$ & \\
\hline No & $440(93.8 \%)$ & $29(6.2 \%)$ & \\
\hline Playing outdoors & & & 0.010 \\
\hline Yes & $240(88.9 \%)$ & $30(11.1 \%)$ & \\
\hline No & $233(95.1 \%)$ & $12(4.9 \%)$ & \\
\hline Respiratory problems preventing activities & & & 0.006 \\
\hline Yes & 27 (79.4\%) & $7(20.6 \%)$ & \\
\hline No & $445(92.7 \%)$ & $35(7.3 \%)$ & \\
\hline Premature birth & & & 0.006 \\
\hline Yes & $21(77.8 \%)$ & $66(22.2 \%)$ & \\
\hline No & 451 (92.6\%) & $36(7.4 \%)$ & \\
\hline Hospitalization after birth & & & 0.080 \\
\hline Yes & $25(83.3 \%)$ & $5(16.7 \%)$ & \\
\hline No & 447 (92.4\%) & 37 (7.6\%) & \\
\hline Attending kindergarten & & & 0.028 \\
\hline Yes & 254 (89.4\%) & $30(10.6 \%)$ & \\
\hline No & $218(94.8 \%)$ & $12(5.2 \%)$ & \\
\hline Mother - smoking & & & 0.048 \\
\hline No & 331 (94.0\%) & $21(6.0 \%)$ & \\
\hline Cigarette & $41(85.4 \%)$ & $7(14.6 \%)$ & \\
\hline Waterpipe & 98 (87.5\%) & 14 (12.5\%) & \\
\hline Cigarette and waterpipe & 2 (100.0\%) & $0(0.0 \%)$ & \\
\hline Father with food allergy & & & $<0.001$ \\
\hline Yes & $6(60.0 \%)$ & $4(40.0 \%)$ & \\
\hline No & 466 (92.5\%) & $38(7.5 \%)$ & \\
\hline Brother with food allergy & & & 0.024 \\
\hline Yes & $4(66.7 \%)$ & $2(33.3 \%)$ & \\
\hline No & $468(92.1 \%)$ & $40(7.9 \%)$ & \\
\hline Father with medications allergy & & & 0.002 \\
\hline Yes & $2(50.0 \%)$ & $2(50.0 \%)$ & \\
\hline No & $471(92.2 \%)$ & $40(7.8 \%)$ & \\
\hline Sister with seasonal allergy & & & 0.005 \\
\hline Yes & $10(71.4 \%)$ & $4(28.6 \%)$ & \\
\hline No & 463 (92.4\%) & $38(7.6 \%)$ & \\
\hline Asthma in a family member (mother) & & & 0.001 \\
\hline Yes & $8(66.7 \%)$ & $4(33.3 \%)$ & \\
\hline No & $465(92.4 \%)$ & $38(7.6 \%)$ & \\
\hline Asthma in a family member (father) & & & 0.005 \\
\hline Yes & $6(66.7 \%)$ & $3(33.3 \%)$ & \\
\hline No & 467 (92.3\%) & 39 (7.7\%) & \\
\hline Asthma in a family member (sister) & & & $<0.001$ \\
\hline Yes & $1(25.0 \%)$ & $3(75.0 \%)$ & \\
\hline No & $472(92.4 \%)$ & $39(7.6 \%)$ & \\
\hline Asthma in a family member (brother) & & & 0.019 \\
\hline Yes & $8(1.7 \%)$ & $3(7.1 \%)$ & \\
\hline No & 465 (98.3\%) & $39(92.9 \%)$ & \\
\hline Asthma in a family member (others) & & & 0.002 \\
\hline Yes & $13(72.2 \%)$ & $5(27.8 \%)$ & \\
\hline No & $460(92.6 \%)$ & 37 (7.4\%) & \\
\hline
\end{tabular}


Table 3 Continued.

\begin{tabular}{|c|c|c|c|}
\hline & $\begin{array}{l}\text { Absence of asthma in child } \\
\qquad N=473(91.8 \%)\end{array}$ & $\begin{array}{l}\text { Presence of asthma in child } \\
\qquad N=42(8.2 \%)\end{array}$ & p-value \\
\hline Allergic rhinitis in family members (sister) & & & $<0.001$ \\
\hline Yes & $0(0.0 \%)$ & $3(100.0 \%)$ & \\
\hline No & $473(92.4 \%)$ & $39(7.6 \%)$ & \\
\hline Allergic rhinitis in family members (brother) & & & 0.009 \\
\hline Yes & $3(60.0 \%)$ & $2(40.0 \%)$ & \\
\hline No & 470 (92.2\%) & $40(7.8 \%)$ & \\
\hline Child reflux & & & 0.009 \\
\hline Yes & $35(81.4 \%)$ & $8(18.6 \%)$ & \\
\hline No & 437 (92.8\%) & 34 (7.2\%) & \\
\hline Eczema before 2 years & & & 0.036 \\
\hline Yes & $28(82.4 \%)$ & $6(17.6 \%)$ & \\
\hline No & $445(92.5 \%)$ & 36 (7.5\%) & \\
\hline Skin rash for at least 6 months & & & 0.066 \\
\hline Yes & $24(82.8 \%)$ & $5(17.2 \%)$ & \\
\hline No & 449 (92.4\%) & 37 (7.6\%) & \\
\hline Heating home using wood & & & 0.086 \\
\hline Yes & $33(84.6 \%)$ & $6(15.4 \%)$ & \\
\hline No & $440(92.4 \%)$ & $36(7.6 \%)$ & \\
\hline Yes & $326(93.4 \%)$ & $23(6.6 \%)$ & \\
\hline No & $147(88.6 \%)$ & $19(11.4 \%)$ & \\
\hline Place of the heating system & & & 0.001 \\
\hline Sitting room & $165(91.7 \%)$ & $15(8.3 \%)$ & \\
\hline Bedroom & $6(60.0 \%)$ & $4(40.0 \%)$ & \\
\hline \multirow[t]{2}{*}{ All the house } & $295(93.4 \%)$ & $21(6.6 \%)$ & \\
\hline & Mean \pm SD & Mean \pm SD & \\
\hline Alcohol glasses per week during pregnancy & $0.08 \pm 0.30$ & $0.03 \pm 0.17$ & 0.092 \\
\hline Alcohol glasses per week during breastfeeding & $0.04 \pm 0.27$ & $0.001 \pm 0.001$ & $<0.001$ \\
\hline Hygiene hypothesis total score & $74.76 \pm 18.91$ & $76.21 \pm 16.30$ & 0.630 \\
\hline
\end{tabular}

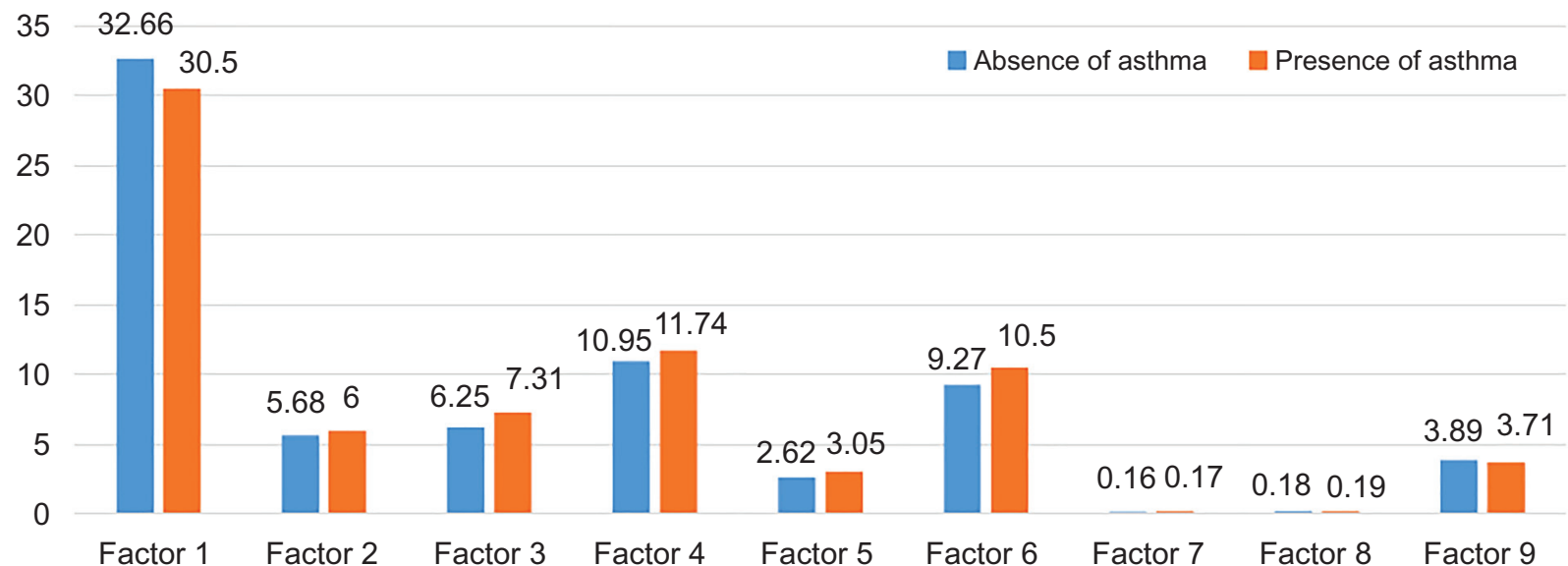

Figure 1 Mean scores of hygiene hypothesis factors between asthmatic and non-asthmatic children. Factor 1: cleaning the house $(p=0.236)$; Factor 2 : washing hands before eating $(p=0.426)$; Factor 3 : washing hands after playing outside $(p=0.491)$; Factor 4 : showering (body and hair) $(p=0.136)$; Factor 5: level of the bedrooms in the house $(p=0.121)$; Factor 6: indoor swimming pool and washing hands after toilet use $(p=0.072)$; Factor 7: presence of compost in/out the house $(p=0.902)$; Factor 8: presence of animals in the house $(p=0.863)$; Factor 9: nails biting and cutting $(p=0.542)$. 
Table 4 Multivariable analysis: logistic regression taking the presence/absence of asthma in a child as the dependent variable and the hygiene hypothesis score as an independent variable.

\begin{tabular}{|c|c|c|c|c|}
\hline & \multirow[t]{2}{*}{$\mathrm{p}$} & \multirow[t]{2}{*}{ ORa } & \multicolumn{2}{|c|}{ Confidence interval } \\
\hline & & & Lower bound & Upper bound \\
\hline Gender (females vs. males*) & 0.042 & 0.41 & 0.17 & 0.97 \\
\hline Living near a prairie sprayed with pesticides (yes vs. no*) & 0.016 & 3.09 & 1.24 & 7.73 \\
\hline Heating system in the house (compared to sitting room*) & 0.004 & & & \\
\hline Bedroom & 0.010 & 9.97 & 1.73 & 57.53 \\
\hline All the house & 0.143 & 0.52 & 0.22 & 1.25 \\
\hline Kindergarten (yes vs. no*) & 0.028 & 2.80 & 1.12 & 7.04 \\
\hline Mother smoking (compared to no*) & 0.038 & & & \\
\hline Cigarette & 0.052 & 3.15 & 0.99 & 10.02 \\
\hline Waterpipe & 0.009 & 3.34 & 1.36 & 8.25 \\
\hline Mother's history of asthma (yes vs. no*) & 0.032 & 5.50 & 1.16 & 26.03 \\
\hline Respiratory infections (yes vs. no*) & $<0.001$ & 14.72 & 5.97 & 36.29 \\
\hline Hygiene hypothesis score & 0.881 & 1 & 0.97 & 1.03 \\
\hline
\end{tabular}

Numbers in bold indicate significant $p$-values.

Variable(s) entered: gender, living prairie, playing outdoors, respiratory problems forbidding daily activities, wood, electricity, place heating system, premature birth, hospitalization after birth, kindergarten, mother smoking, family member allergy, food allergy father, food allergy brother, medication allergy father, seasonal allergy sister, asthma family members mother, asthma family members father, asthma family members brother, child reflux, Respiratory infections before 2 years of age, eczema before 2 years old, skin rash for at least 6 months, alcohol glasses per week during pregnancy, hygiene hypothesis score.

showed that higher odds of asthma in children were significantly associated with male gender (ORa $=0.41$ for females), living near a prairie sprayed with pesticides $(\mathrm{ORa}=3.09)$, having a heating system in the bedroom compared to the sitting room $(\mathrm{ORa}=9.97)$, attending kindergarten $(\mathrm{ORa}=2.80)$, having a mother who smokes waterpipe compared to not smoking $(\mathrm{ORa}=3.34)$, having a mother with a history of asthma $(\mathrm{ORa}=5.50)$, and having respiratory infections $(\mathrm{ORa}=14.72)$. The hygiene hypothesis score was not associated with higher odds of asthma $(p=0.881)$ (Table 4).

\section{Discussion}

In this study, the hygiene hypothesis scale items converged over a solution of nine factors that had an Eigenvalue over 1 , explaining a total of $65.86 \%$ of the variance. An acceptable Cronbach's alpha value was recorded for the hygiene hypothesis scale $(0.696)$, thus showing that the scale can be used in the Lebanese population. It was not possible to compare the properties of this scale to those of another, because the authors of the original scale had not validated the questionnaire they used and, to our knowledge, there is no other validated scale to measure the hygiene hypothesis.

In addition, this study could not demonstrate the effect of hygiene measures on asthma but found other factors, already known to be associated with asthma, to be associated with it. The results of the multivariable analysis showed that placing a heating system only in the bedroom was associated with higher asthma in preschool children, whereas installing a heating system in the whole house was associated with lower asthma, in agreement with previous findings. ${ }^{43}$ Indeed, one study has shown that insulating the house made the indoor environment warmer and drier and led to an improvement in wheezing, school absence, and hospital visits due to respiratory conditions. ${ }^{44}$

In addition, smoking cigarettes and waterpipe inside the house were significantly associated with higher odds of asthma in children. The results consolidate those from previous studies in Lebanon. ${ }^{39,40}$ A systematic review estimated that among children with asthma, those exposed to second-hand smoke are nearly twice as likely to be hospitalized with an acute asthma episode and have poorer pulmonary function test results \{reference 43$\}$. The prevalence of asthma is higher among children living in households with smokers, and the risk of developing asthma increases in proportion to the number of smokers at home. ${ }^{46}$ Despite this available evidence, the waterpipe is still wrongly considered by smokers to be less dangerous and less toxic than cigarettes. ${ }^{47}$ In fact, pregnant and nursing women may stop smoking cigarettes but not a waterpipe, and this was shown to increase the risk of asthma and allergies among Lebanese children. ${ }^{40}$ Furthermore, children are often allowed to play in closed rooms with ongoing waterpipe smoking, because waterpipes are wrongly perceived as less addictive and less harmful (containing less nicotine) than cigarettes. ${ }^{47}$

Having a parental history of asthma or seasonal allergy were significantly associated with higher odds of asthma in preschoolers, in line with results of previous studies showing that parental asthma is a risk factor associated with atopic wheezing in children. ${ }^{48}$

Early respiratory infections were found to be associated with higher asthma in children, in both bivariate and 
multivariable analyses. Our results are consistent with those of a study showing that asthma is associated with exposure to the respiratory syncytial virus during infancy. ${ }^{37}$ Studies have also shown that viral infections of the lower respiratory tract alter the development of the respiratory/ immune system, increasing the likelihood of developing asthma, specifically in predisposed children..$^{49,50}$

As for the hygiene hypothesis, to the best of our knowledge, this study is the first to use a validated scale to assess the association between the hygiene hypothesis theory and asthma in preschool children. House cleaning behaviors and individual cleanliness habits (related to washing the child's hands, showering, etc.) were investigated using a comprehensive validated questionnaire of more than 40 relevant items. After adjusting for all sociodemographic, socioeconomic, and other factors described in the literature as being associated with asthma, the results of the multivariable analysis showed that the hygiene hypothesis scale was not significantly associated with asthma among this population group; thus, hygiene measures were not associated with asthma among Lebanese children. Our results are consistent with other studies that were carried out in developing countries (although in different geographic areas). Findings from a Latin American systematic review revealed that most studies did not show an association between hygiene and wheezing or asthma, with the exception of a generally increased risk associated with acute respiratory infections in early life. Therefore, no clear inferences could be drawn to explain the prevalence of asthma among LatinAmerican children and the role of poor hygiene exposure. ${ }^{30}$ However, besides the real absence of association, the lack of association between hygiene measures and asthma could be explained by several factors, including the small sample that could result in an inadequate power, which raises the possibility of false-negative findings. A selection bias is possible due to the refusal rate and the fact that the study was conducted in three of the five districts in Lebanon, which might not be representative of the whole population. Additionally, the study methods might have also led to the underestimation of the association between hygiene measures and asthma: an information bias is possible since the use of a questionnaire in surrogate responders (parents) may not always be accurate due to problems in understanding questions, recall, and over- or under-evaluating symptoms. Asthma might have been over or under-diagnosed when answering questions about a physician's diagnosis, and the exposure to toxicants over or under-estimated by the parents, as it was subjectively evaluated and quantified. For known risk factors of asthma, the impact of recall bias could be differential and lead to the overestimation of effects by parents of children with the disease. However, for the substances that are not known to be associated with asthma, the bias is mainly non-differential, and the association with asthma is expected to be underestimated. As the hygiene hypothesis is relatively unknown in Lebanon, it is expected that the bias is non-differential, and lead to an underestimation of the above association.

Furthermore, some other factors related to the hygiene hypothesis may not have been taken into consideration because of the limited funds to carry out this project, which might have resulted in residual confounding. The factors that could not be studied were the assessment of the flora in children and mothers and the classification of the living area in rural or urban, because there is no official classification in Lebanon for rural and urban areas.

Despite all the possible limitations, the overall validity of our results is acceptable since our methodology is similar to other cross-sectional studies, including the ISAAC set of studies that are widely used for international comparisons. However, our results cannot be generalizable to the whole population. One point that further corroborates this idea is that factors already known to be risk factors for asthma were found to be associated with it, validating our finding as a positive control. Consequently, larger prospective studies that outweigh information bias are expected to improve the accuracy of our results, but not to change them. Also, studies that measure the intensity and duration of exposure to each toxicant are suggested to better assess the hygiene hypothesis items.

\section{Conclusions}

This study is the first of its kind in Lebanon and aimed at examining the association between the hygiene hypothesis and asthma in preschool children. The current results suggest that neither home cleaning nor personal cleanliness was correlated with asthma in Lebanese preschool children. Larger prospective studies that measure the intensity and duration of exposure to each toxicant are suggested to better assess the hygiene hypothesis items and their association with asthma.

\section{Acknowledgments}

We would like to thank all parents who agreed to take part in the study.

\section{Conflicts of interests}

The authors report no conflicts of interest.

\section{Funding}

This study was funded by the Lebanese University.

\section{Ethical approval and consent to participate}

The Ethics and Research Committee at the Psychiatric Hospital of the Cross has approved this study (HPC-0072019). The participants were informed about the objective and requirement of the study, and the written consent was taken from the child's parents.

\section{Authors' contribution}

SH and PS conceived and designed the study. NK performed the data collection and entry. PS and SH were involved in data interpretation and statistical analysis. SH and PS 
wrote the manuscript. HS edited the paper for the English language and intellectual content. $\mathrm{RH}, \mathrm{EH}$, and $\mathrm{MW}$ critically revised the manuscript for intellectual content. All authors read and approved the final manuscript.

\section{Availability of data and materials}

There is no public access to all data generated or analyzed during this study to preserve the privacy of the identities of the individuals. The dataset that supports the conclusions is available to the corresponding author upon request.

\section{References}

1. Barnes PJ. Against the Dutch hypothesis: asthma and chronic obstructive pulmonary disease are distinct diseases. Am J Respir Crit Care Med. 2006;174(3):240-243; discussion 243-244. https://doi.org/10.1164/rccm.2604008

2. Pearce N, Ait-Khaled N, Beasley R, Mallol J, Keil U, Mitchel E et al. Worldwide trends in the prevalence of asthma symptoms: phase III of the International Study of Asthma and Allergies in Childhood (ISAAC). Thorax. 2007;62(9):758-766. https://doi.org/10.1136/thx.2006.070169

3. Strachan DP. Hay fever, hygiene, and household size. BMJ. 1989;299(6710):1259-1260. https://doi.org/10.1136/bmj.299. 6710.1259

4. Strachan DP. Family size, infection and atopy: the first decade of the "hygiene hypothesis". Thorax. 2000;55 Suppl 1:S2-S10. https://doi.org/10.1136/thorax.55.suppl_1.s2

5. U.S. Food and Drug Administration. What do clean houses have in common with childhood infections? Available from: http://www.fda.gov/BiologicsBloodVaccines/ResourcesforYou/ Consumers/ucm167471.htm. 2018. Accessed on August 18, 2019.

6. Ege MJ, Bieli C, Frei R, can Strien RT, Riedler J, Ublagger E, et al. Prenatal farm exposure is related to the expression of receptors of the innate immunity and to atopic sensitization in school-age children. J Allergy Clin Immunol. 2006;117(4):817823. https://doi.org/10.1016/j.jaci.2005.12.1307

7. Weber J, Illi S, Nowak D, Schierl R, Holst O, von Mutius E, et al. Asthma and the hygiene hypothesis. Does cleanliness matter? Am J Respir Crit Care Med. 2015;191(5):522-529. https://doi.org/10.1164/rccm.201410-18990C

8. Romano-Keeler J, Weitkamp JH. Maternal influences on fetal microbial colonization and immune development. Pediatr Res. 2015;77(1-2):189-195. https://doi.org/10.1038/pr.2014.163

9. Shanahan F, Quigley EM. Manipulation of the microbiota for treatment of IBS and IBD-challenges and controversies. Gastroenterology. 2014;146(6):1554-1563. https://doi. org/10.1053/j.gastro.2014.01.050

10. Scudellari M. News feature: cleaning up the hygiene hypothesis. Proc Natl Acad Sci USA. 2017;114(7):1433-1436.https://doi. org/10.1073/pnas.1700688114

11. Bloomfield SF, Rook GA, Scott EA, Shanahan F, StanwellSmith R, Turner P. Time to abandon the hygiene hypothesis: new perspectives on allergic disease, the human microbiome, infectious disease prevention and the role of targeted hygiene. Perspect Public Health. 2016;136(4):213-224. https:// doi.org/10.1177/1757913916650225

12. Lapin B, Piorkowski J, Ownby D, Freels S, Chavez N, Hernandez E, et al. Relationship between prenatal antibiotic use and asthma in at-risk children. Ann Allergy Asthma Immunol. 2015;114(3):203-207. https://doi.org/10.1016/j.anai.2014.11.014

13. Metsala J, Lundqvist A, Virta LJ, Kaila M, Gissler M, Virtanen SM. Prenatal and post-natal exposure to antibiotics and risk of asthma in childhood. Clin Exp Allergy. 2015;45(1):137-145. https://doi.org/10.1111/cea.12356

14. Sonnenburg ED, Smits SA, Tikhonov M, Higginbottom SK, Wingreen NS, Sonnenburg JL. Diet- induced extinctions in the gut microbiota compound over generations. Nature. 2016;529(7585):212-215. https://doi.org/10.1038/nature16504

15. Figueiredo CA, Alcantara-Neves NM, Amorim LD, Silva NB, Pontes de Carvalho LC, Cooper P, et al. Evidence for a modulatory effect of IL-10 on both Th1 and Th2 cytokine production: the role of the environment. Clin Immunol. 2011;139(1):57-64. https://doi.org/10.1016/j.clim.2010.12.019

16. Ajdacic-Gross V, Mutsch $M$, Rodgers $S$, Tesic A, Muller $M$, Seifritz E, et al. A step beyond the hygiene hypothesisimmune-mediated classes determined in a population-based study. BMC Med. 2019;17(1):75. https://doi.org/10.1186/ s12916-019-1311-z

17. Cooper P. Toxocara canis infection: an important and neglected environmental risk factor for asthma? This editorial discusses the findings of the paper in this issue by $\mathrm{E}$. Pinelli et al. [19], pp. 649-658. Clin Exp Allergy. 2008;38(4):551-553. https://doi.org/10.1111/j.1365-2222.2008.02934.x

18. van Tilburg Bernardes E, Arrieta M-C. Hygiene hypothesis in asthma development: Is hygiene to blame? Arch Med Res. 2017;48(8):717-726. https://doi.org/10.1016/j. arcmed.2017.11.009

19. Benn CS, Melbye M, Wohlfahrt J, Bjorksten B, Aaby P. Cohort study of sibling effect, infectious diseases, and risk of atopic dermatitis during first 18 months of life. BMJ. 2004;328(7450):1223. https://doi.org/10.1136/bmj. 38069.512245.FE

20. Jeong JS, Choi JK, Jeong IS, Paek KR, In HK, Park KD. [A nationwide survey on the hand washing behavior and awareness]. J Prev Med Public Health. 2007;40(3):197-204. https:// doi.org/10.3961/jpmph.2007.40.3.197

21. Haas JP, Larson EL. Measurement of compliance with hand hygiene. J Hosp Infect. 2007;66(1):6-14. https://doi. org/10.1016/j.jhin.2006.11.013

22. Stevenson RJ, Case TI, Hodgson D, Porzig-Drummond R, Barouei J, Oaten MJ. A scale for measuring hygiene behavior: development, reliability and validity. Am J Infect Control. 2009;37(7):557-564. https://doi.org/10.1016/j.ajic.2009.01.003

23. Sordillo JE, Hoffman EB, Celedon JC, Litonjua AA, Milton DK, Gold DR. Multiple microbial exposures in the home may protect against asthma or allergy in childhood. Clin Exp Allergy. 2010;40(6):902-910.

24. Schaub B, Lauener R, von Mutius E. The many faces of the hygiene hypothesis. J Allergy Clin Immunol. 2006;117(5):969977; quiz 978. https://doi.org/10.1016/j.jaci.2006.03.003

25. Weinmayr G, Weiland SK, Bjorksten B, Brunekreef B, Buchele $\mathrm{G}$, Cookson W, et al. Atopic sensitization and the international variation of asthma symptom prevalence in children. Am J Respir Crit Care Med. 2007;176(6):565-574. https://doi. org $/ 10.1164 / \mathrm{rccm} .200607-9940 \mathrm{C}$

26. van Dijk CE, Garcia-Aymerich J, Carsin A-E, Smit LAM, Borlée $F$, Heederick DJJ, et al. Risk of exacerbations in COPD and asthma patients living in the neighbourhood of livestock farms: observational study using longitudinal data. Int J Hyg Environ Health. 2016;219(3):278-287. https://doi. org/10.1183/13993003.congress-2015.0A2912

27. Kramer M, Matush L, Bogdanovich N, Dahhou M, Platt R, Mazer B. The low prevalence of allergic disease in Eastern Europe: Are risk factors consistent with the hygiene hypothesis? Clin Exp Allergy. 2009;39(5):708-716. https://doi. org/10.1111/j.1365-2222.2009.03205.x

28. Braun-Fahrlander C, Riedler J, Herz U, Eder W, Waser M, Grize L, et al. Environmental exposure to endotoxin and its relation to asthma in school-age children. N Engl J Med. 2002;347(12):869-877. https://doi.org/10.1056/NEJMoa020057 
29. Cooper PJ, Vaca M, Rodriguez A, Chico ME, Santos DN, Rodrigues LC, et al. Hygiene, atopy and wheeze-eczemarhinitis symptoms in schoolchildren from urban and rural Ecuador. Thorax. 2014;69(3):232-239. https://doi.org/10.1136/ thoraxjnl-2013-203818

30. Ardura-Garcia C, Garner P, Cooper PJ. Is childhood wheeze and asthma in Latin America associated with poor hygiene and infection? A systematic review. BMJ Open Respir Res. 2018;5(1):e000249. https://doi.org/10.1136/ bmjresp-2017-000249

31. Waked $M$, Salameh P. Asthma, allergic rhinitis and eczema in 5-12-year-old school children across Lebanon. Public Health. 2008;122(9):965-973. https://doi.org/10.1016/j. puhe.2007.10.006

32. Hallit S, Raherison C, Malaeb D, Hallit R, Kheir N, Salameh P. The AAA risk factors scale: a new model to screen for the risk of asthma, allergic rhinitis and atopic dermatitis in children. Med Princ Pract. 2018;27(5):472-480. https://doi. org/10.1159/000490704

33. Hallit S, Raherison C, Malaeb D, Hallit R, Waked M, Kheir N, et al. Development of an asthma risk factors scale (ARFS) for risk assessment asthma screening in children. Pediatr Neonatol. 2019;60(2):156-165. https://doi.org/10.1016/j. pedneo.2018.05.009

34. Hallit S, Raherison C, Waked M, Hallit R, Layoun N, Salameh P. Validation of the mini pediatric asthma quality of life questionnaire and identification of risk factors affecting quality of life among Lebanese children. J Asthma. 2019;56(2):200-210. https://doi.org/10.1080/02770903.2018.1441417

35. Malaeb D, Hallit S, Sacre H, Hallit R, Salameh P. Factors associated with wheezing among Lebanese children: Results of a cross-sectional study. Allergologia et Immunopathologia, 2021, https://doi.org/10.1016/j.aller.2020.02.003

36. Castro-Rodriguez JA, Forno E, Rodriguez-Martinez CE, Celedon JC. Risk and protective factors for childhood asthma: What is the evidence? J Allergy Clin Immunol Pract. 2016;4(6): 1111-1122. https://doi.org/10.1016/j.jaip.2016.05.003

37 Malaeb D, Hallit S, Sacre H, Rahme C, Malaeb B, Hallit R, et al. Preconception exposure to over-the-counter medications and antibiotics and the risk of childhood asthma in Lebanon: A cross-sectional study. Allergologia et immunopathologia. 2020;48:523-9.

38. Carson CG, Halkjaer LB, Jensen SM, Bisgaard H. Alcohol intake in pregnancy increases the child's risk of atopic dermatitis: the COPSAC prospective birth cohort study of a high risk population. PLoS One. 2012;7(8):e42710. https://doi.org/10.1371/ journal.pone.0042710

39. Hallit S, Raherison C, Waked M, Salameh P. Association between caregiver exposure to toxics during pregnancy and childhood-onset asthma: a case-control study. Iran J Allergy Asthma Immunol. 2017;16(6):488-500.

40. Hallit S, Salameh P. Exposure to toxics during pregnancy and childhood and asthma in children: a pilot study. J Epidemiol Glob Health. 2017;7(3):147-154.
41. Thavagnanam S, Fleming J, Bromley A, Shields MD, Cardwell CR A meta-analysis of the association between Caesarean section and childhood asthma. Clin Exp Allergy. 2008;38(4):629- 633. https://doi.org/10.1111/j.1365-2222.2007.02780.x

42. Zock JP, Plana E, Jarvis D, Anto J, Kromhout H, Kennedy S, et al. The use of household cleaning sprays and adult asthma: an international longitudinal study. Am J Respir Crit Care Med. 2007;176(8):735-741. https://doi.org/10.1164/ rccm.200612-17930C

43. Howden-Chapman P, Pierse N, Nicholls S, Gillespie-Bennett J, Viggers $\mathrm{H}$, Cunningham $\mathrm{M}$, et al. Effects of improved home heating on asthma in community dwelling children: randomised controlled trial. BMJ. 2008;337:a1411. https://doi. org/10.1136/bmj.a1411

44. Howden-Chapman P, Matheson A, Crane J, Viggers $H$, Cunningham M, Blakely $T$, et al. Effect of insulating existing houses on health inequality: cluster randomised study in the community. BMJ. 2007;334(7591):460. https://doi.org/10.1136/ bmj.39070.573032.80

45. Wang Z, May SM, Charoenlap S, Pyle R, Ott NL, Mohammed K, et al. Effects of secondhand smoke exposure on asthma morbidity and health care utilization in children: a systematic review and meta-analysis. Ann Allergy Asthma Immunol. 2015; 115(5):396-401, e392. https://doi.org/10.1016/j.anai.2015. 08.005

46. Office on Smoking and Health (US). The Health Consequences of Involuntary Exposure to Tobacco Smoke: A Report of the Surgeon General. Atlanta (GA): Centers for Disease Control and Prevention (US); 2006. Available from: https://www.ncbi. nlm.nih.gov/books/NBK44324/

47. Hallit, S., Haddad, C., Bou Malhab, S. Rabbaa Khabbaz L, Salameh P. Construction and validation of the water pipe harm perception scale (WHPS-6) among the Lebanese population. Environ Sci Pollut Res 27, 3440-3448 (2020). https://doi. org/10.1007/s11356-019-07247-8

48. Guilbert TW, Morgan WJ, Zeiger RS, Bacharier LB, Boehmer SJ, Krawiec $M$, et al. Atopic characteristics of children with recurrent wheezing at high risk for the development of childhood asthma. J Allergy Clin Immunol. 2004;114(6):1282-1287. https://doi.org/10.1016/j.jaci.2004.09.020

49. Jackson DJ, Gangnon RE, Evans MD, Roberg KA, Anderson EL, Pappas TE, et al. Wheezing rhinovirus illnesses in early life predict asthma development in high-risk children. Am J Respir Crit Care Med. 2008;178(7):667-672. https://doi.org/10.1164/ rccm.200802-3090C

50. Hallit S, Leynaert B, Delmas MC, Rocchi S, De Blic J, Marguet C, et al. Wheezing phenotypes and risk factors in early life: The ELFE cohort. PLoS One. 2018 Apr 27;13(4):e0196711. https:// doi.org/10.1371/journal.pone.0196711. 